\title{
A study of the evolution of specific and non-specific immune complexes in acute hepatitis B and chronic hepatitis
}

\author{
A. LEYVA, M. C. BERNAL, G. PIEDROLA and M. C. MAROTO
}

Department of Microbiology, School of Medicine, Avd. Madrid 11, 18012 Granada, Spain

\begin{abstract}
Summary. Circulating immune complexes (ICs) containing IgG and $\mathrm{HBsAg}$, and $\mathrm{IgG}$ and $\mathrm{HBeAg}$, in sera from groups of patients with various liver diseases were sought by ELISA and immunodiffusion. A correlation was found between the absence of ICs and the disappearance of $\mathrm{HBsAg}$ in patients who had recovered from acute hepatitis $\mathrm{B}$, but complexes containing HBsAg were always found in chronic hepatitis.
\end{abstract}

\section{Introduction}

The lesions of "immune complex disease" are caused by the deposition in tissues of circulating antigen-antibody complexes (Germuth et al., 1967; McCluskey et al., 1971). Immune complexes (ICs) have been demonstrated in numerous conditions, in health and disease. The presence of ICs has been demonstrated in hepatitis B (Almeida and Waterson, 1969; Araki et al., 1982) and certain diseases related to hepatitis B virus (HBV) infection (Alpert et al., 1971; Prince and Trepo, 1971; Carella et al., 1977; Furuse et al., 1982).

This study of 39 patients with acute hepatitis B and chronic $\mathrm{HBsAg}$-positive hepatopathy examines the occurrence and development of ICs.

\section{Materials and methods}

The progress of 22 patients with acute hepatitis B (AHB) and 17 patients with chronic HBsAg-positive hepatopathies $(\mathrm{CH} \mathrm{HBsAg}+)$ was studied for 2-12 months, depending upon the condition of each patient.

Sera were tested by ELISA (Abbot) for HBsAg, antiHBs, antiHBc, $\mathrm{HBeAg}$ and antiHBe.

Blood was tested for circulating ICs by two methods. (i) Precipitation with polyethylene glycol (PEG) 6000 ( $2 \%$ final concentration) and subsequent identification of ICs by simple immunodiffusion (ID) (Behring). This test detects ICs formed by IgG and any type of antigen. For this reason we refer to them as "non-specific" (non-sp) ICs. (ii) Precipitation with PEG $6000(2 \%$ final concentration) and identification of $\mathrm{HBsAg}$ ICs and $\mathrm{HBeAg} \mathrm{ICs}$

Received 9 Feb. 1987; revised version accepted 7 Nov. 1987. in the precipitate by ELISA, Auszyme II and $\mathrm{HbeAg}$ / antiHBe ELISA, respectively.

These techniques were slightly modified by a change of the controls and the introduction of a correction factor for interpreting the results (Leyva et al., 1987).

\section{Results}

Table I shows the results obtained with the 22 AHB patients studied. In the first serum samples, 19 patients had HBsAg as well as HBs ICs and three patients had only HBsAg. Second samples showed no change in 13 of the 19 patients, whereas the other six had lost both antigen and complexes. The three patients with HBsAg only also had negative results with second samples.

$\mathrm{HBe}$ ICs were found in four of the five $\mathrm{HBeAg}$ positive patients and there was no change during the period of study.

When non-specific ICs were studied in relation to the presence of HBsAg, the number of patients with both HBsAg and non-sp ICs stayed the same in the two samples. Of the $18 \mathrm{HBsAg}$-positive patients without non-sp ICs, seven remained unchanged, two retained HBsAg and acquired nonsp ICs and nine lost their HBsAg.

We did not attempt to establish a relationship between non-sp ICs and $\mathrm{HBeAg}$ because the latter is not found in the absence of HBsAg.

HBsAg ICs were found in all 17 cases of $\mathrm{CH}$ HBsAg + (table II).

HBeAg ICs were found in five out of the seven patients with $\mathrm{HBeAg}$ in serum. These findings did not change during the study. The only change in 
Table I. Evolution of HBsAg ICs, HBeAg ICs and non-specific ICs in relation to $\mathrm{HBs}$ and $\mathrm{HBe}$ antigens in 22 patients with acute hepatitis $\mathrm{B}$

\begin{tabular}{|c|c|c|c|}
\hline \multicolumn{2}{|c|}{ Results obtained with first serum sample } & \multicolumn{2}{|c|}{$\begin{array}{l}\text { Results obtained with second serum } \\
\text { sample }\end{array}$} \\
\hline $\mathrm{HBsAg}+; \mathrm{HBsAg} \mathrm{IC}+$ & 19 & $\begin{array}{c}13 \\
6\end{array}$ & $\begin{array}{l}\text { HBsAg }+; \text { HBsAg IC }+ \\
\text { HBsAg }-; \text { HBsAg } 1 \mathrm{C}-\end{array}$ \\
\hline $\mathrm{HbsAg}+\mathrm{HBsAg} \mathrm{IC}-$ & 3 & 3 & HBsAg - ; HBsAg IC - \\
\hline $\mathrm{HBeAg}+; \mathrm{HBeAg} \mathrm{IC}+$ & 4 & 4 & $\mathrm{HBeAg}+; \mathrm{HBeAg} \mathrm{IC}+$ \\
\hline $\mathrm{HBeAg}+; \mathrm{HBeAg} \mathrm{IC}-$ & 1 & 1 & $\mathrm{HBeAg}+; \mathrm{HBeAg} \mathrm{IC}-$ \\
\hline $\mathrm{HBeAg}-; \mathrm{HBeAg} \mathrm{IC}-$ & 17 & 17 & $\mathrm{HBeAg}-; \mathrm{HBeAg} \mathrm{IC}-$ \\
\hline HBsAG + ; non-spIC + & 4 & 4 & HBsAg + ; non-sp IC + \\
\hline $\mathrm{HBsAg}+$ non-sp IC - & 18 & $\begin{array}{l}7 \\
2 \\
9\end{array}$ & $\begin{array}{l}\mathrm{HBsAg}+; \text { non-sp IC }- \\
\mathrm{HBsAg}+\text {; non-sp IC + } \\
\mathrm{HBsAg}+; \text { non-sp IC }+\end{array}$ \\
\hline
\end{tabular}

second samples from these patients was the appearance of non-sp ICs in three initially without them.

\section{Discussion}

Recently, the importance of circulating immune complexes in numerous diseases has been discussed more frequently (Report, 1977). It is generally assumed that ICs in slight antigen excess may be responsible for the development of IC disease (Pernice and Sedlacek, 1979).

The surveillance of 39 patients diagnosed as having acute hepatitis B or chronic HBsAg-positive hepatopathies has enabled us to make some noteworthy observations.

The absence of HBsAg ICs in three patients with AHB who were still HBsAg-positive (table I) could be a finding indicating a favourable outcome for the patients, because their second serum samples showed that they had lost their HBsAg and were recovering from the disease. Moreover, in all the patients who retained their ICs, as noted by Pernice and Sedlacek (1979), a good correlation was found between the level of HBsAg-containing immune complexes and the clinical state. ICs could be detected simultaneously with HBsAg and either decreased or disappeared before the appearance of free antiHBs. However, authors such as Nydegger et al. (1974) observed that the order of appearance of the various reactants in building up immune complexes during $\mathrm{HBV}$ infection may be variable; circulating immune complexes may be formed 2-3 months after HBV infection. Careoda et al. (1982) observed that the persistence of ICs in the early phase of acute hepatitis could indicate impending

Table II. Evolution of HBsAG ICs, HBeAg ICs and non-specific ICs in relation to $\mathrm{HBs}$ and $\mathrm{HBe}$ antigen in 17 patients with chronic hepatopathies

\begin{tabular}{|c|c|c|c|}
\hline \multicolumn{2}{|c|}{ Results obtained with first serum sample } & \multicolumn{2}{|c|}{$\begin{array}{l}\text { Results obtained with second serum } \\
\text { sample }\end{array}$} \\
\hline HBsAg $+;$ HBsAg IC + & 17 & 17 & $\mathrm{HBsAg}+; \mathrm{HBs} \mathrm{IC}+$ \\
\hline $\mathrm{HBsAg}+; \mathrm{HBsAg} \mathrm{IC}-$ & 0 & & $\ldots$ \\
\hline $\mathrm{HBeAg}+; \mathrm{HBeAg} \mathrm{IC}+$ & 5 & 5 & $\mathrm{HBeAg}+; \mathrm{HBeAg} \mathrm{IC}+$ \\
\hline $\mathrm{HBeAg}+; \mathrm{HBeAg} \mathrm{IC}-$ & 2 & 2 & $\mathrm{HBeAg}+; \mathrm{HBeAg} \mathrm{IC} \mathrm{-}$ \\
\hline $\mathrm{HBeAg}-; \mathrm{HBeAg} \mathrm{IC}-$ & 10 & 10 & $\mathrm{HBeAg}-; \mathrm{HBeAg} \mathrm{IC}-$ \\
\hline HBsAg + ; non-sp IC + & 8 & 8 & HBsAg + ; non-sp IC + \\
\hline HBsAg + non-sp IC - & 9 & $\begin{array}{l}6 \\
3\end{array}$ & $\begin{array}{l}\text { HBsAg + ; non-sp IC- } \\
\text { HBsAg + ; non-sp IC + }\end{array}$ \\
\hline
\end{tabular}


chronicity. These findings agree with our results in that HBs ICs were always detected in the chronic hepatopathies. Nevertheless, others (Trepo et al., 1974) believe that no relationship exists between the presence of this type of IC and an unfavourable outcome of the disease.

As the number of patients with $\mathrm{HBe}$ ICs is small we are not able to determine whether the absence of $\mathrm{HBe} \mathrm{ICs}$ in the presence of $\mathrm{HBeAg}$ has any prognostic significance.

\section{REFERENCES}

Almeida J D, Waterson A P 1969 Immune complexes in hepatitis. Lancet 2: 983-986.

Alpert E, Isselbacher K J, Schur P H 1971 The pathogenesis of arthritis associated with viral hepatitis; complementcomponent studies. New England Journal of Medicine 285: $185-189$.

Araki K, Nagashima H, Tsuji T 1982 Detection and characterization of circulating immune complexes during acute exacerbation of chronic viral hepatitis. Clinical and Experimental Immunology 47: 520-526.

Carella G et al. 1977 Detection of hepatitis B antigen in circulating immune complexes in acute and chronic hepatitis. Scandinavian Journal of Immunology 6: 12971304.

Careoda F et al. 1982 Persistence of circulating HBsAg/IgM complexes in acute viral hepatitis type B: an early marker of chronic evolution. Lancet 2: 358-360.

Furuse A, Hattori S, Terashima T, Karashima S, Matsuda I 1982. Circulating immune complex in glomerulonephropathy associated with hepatitis B. Nephron 31 : 212-218.

Germuth F G, Senterfit L B, Pollack A D 1967 Immune complex disease. I. Experimental acute and chronic glomerulonephritis. John Hopkins Medical Journal 120 : 225-251.
The detection of non-specific ICs showed no change in the AHB patients who eliminated HBsAg. On the other hand, the number of non-sp IC-positive cases rose over the period of study in the AHB patients who did not show signs of recovery and in the $\mathrm{CH}$ patients. This observation seems to indicate that the ID technique, which is less sensitive than ELISA, requires time for a buildup of circulating ICs in order that they may be detected.

Leyva A et al. 1987 Influencia de los antigenos del virus de la hepatitis B en la aparición de immunocomplejos circulantes. Laboratorio 83: 53-59.

McCluskey R T, Vassalli P 1971 Serum sickness (immune complex disease). In: Movat $\mathrm{H} \mathrm{Z}$ (ed) Inflammation, immunity and hypersensitivity. Harper and Row, New York, pp 426-457.

Nydegger Y E, Lambert P H, Gerber H, Miescher P A 1974 Circulating immune complexes in the serum in systemic lupus erythematosus and in carriers of hepatitis B antigen. Journal of Clinical Investigation 54 : 297-309.

Pernice W, Sedlacek H 1979 Antigen-specific detection of soluble immune complexes by a solid phase specific antibody system. Journal of Immunological Methods 28: 33-40.

Prince A M, Trepo C 1971 Role of immune complexes involving $\mathrm{SH}$ antigen in pathogenesis of chronic active hepatitis and polyarteritis nodosa. Lancet 1 : 1309-1312.

Report of a WHO Scientific Group 1977 The role of immune complexes in disease. WHO Technical Report Series, WHO, Geneva, p 606.

Trepo C G, Zuckerman A J, Bird R C, Prince A M 1974 The role of circulating hepatitis $B$ antigen/antibody immune complexes in the pathogenesis of vascular and hepatic manifestations in polyarteritis nodosa. Journal of Clinical Pathology 27: 863-868. 